ってその基礎物が遊離して来ると，そこに，簡単な無 機化合物ができる。

（5）この無機化合物が再び上にのぼって，次の春に新し い循環が始まる。

最近の水不足に，こんなことを考えたのである。

\section{中川順 助}

择啓 今回『産業医学』特集号を発行なさるにつき, 何か執筆するよらにとの御手紙を頂き，恐入りました。

老生，住友別子病院に在勤中，貴協会の未席に㧤りま したが，昭和10年，停年退職後，当地（東京・世田谷） に転住，無為にすごしておりますので，格別申上げるよ らな感想もありませんのですから，何卒悪しからず御了 承の程覑上げます。

早々

(9月 4 日のはがき)

\section{思い出すままに}

\section{平松真 兵 衛}

世間の人は老人に対する敬意といらのか，あるいは尊 敬しての意味か，よく失礼ですが貴方は挑幾つですかと 聞かれることが䂺々ある。私は数年来というか，長い間 自分の年令を考えたこともなく，また，このような質問 を受けるのがイヤで，何時も問われたら，御想像に委す と逃げている。

この冊子を手にされる皆さんは，私が相当の老人であ ることは百も御承知のこと，それは名誉会員ということ 自体が私達の老歯であることを示しているからである。 しかし，私は自分の本来からの性格の現われともいらの か，茫然と手を拱いていることができない性格で，何か していないと落付かない。昭和 30 年頃から，知人の推䳡 で学校の衛生学の講義を受持っているが，大正 5 年，工 場法の実施から工場衛生の仕事に関与して以来，とさに 籍は多少転々としたが，この方面の仕事に対する興味は 忘れられない。ことに，昭和 22 年から実施された現労働 基準法の仕事に再び引き出されて参与し,これが一尿, 私 の労㗢衛生に対する関心を深める動機ともなったのであ る。しかし，労動基準法の仕事には自ら年柃の関係もあ って，昭和28年頃から一切手を引いたが，幸か不幸か， 今日学校に関係を持らながらも，もとの労働基準法に関 係をもった時代の友人なり，知人から，時々労衝衛生に 関する相談を受けるので，余睱をつくっては労働者の健
康管理の方面の仕事の手伝いに，時代湹れの者がと笑わ れても, 話の都度, 時間をつくって出かけては手を出す といら風に動いている。

昔から，知人やら友人は御承知のように，私はシャベ ルことは下手，また筆をとることも下手，害にとり得の ない人間である。今は既に故人であるが，我々の大先輩 石原修博士が，ある会談の席で私に，「筆を執ることの 上手下手を気にする必要はない。自分も筆を執ることは 上手でもない。従って，文章も下手だ。しかし，下手で も機会あるごとに畫いて和れば，意は自ら通ずで，人も 読んでくれる。なにも気に病む必要はないから書けよ」 との励ましの言葉を受けたのを覚えている。爾来, 先生 の言葉は忘れずに，下手の横好きとでもいうのか，機会 あるごとに書いている。それが次の題目のように七つば かりあるので，その論文の題だけならべて，老令でもま だ䮈尾に付して動いていることを示し，特笑いの種とし た次第である。

この論文は，いずれも学校の論䟾に掲載した。

1. 学生生徒の健康管理に関する調查

（月経と健康管理） 1956年 論欉 第 1 号

2. B C G接種亡ツ氏反応

1957年 I 第 2 号

3. 性格から見た運動（体育）と月経

1958年 " 第3号

4. B C G接種の特異体質から見たツ氏反応

1959年 " 第 4 号

5. 若年者の高血圧の問題に就て

1960年 / 第 5 号

6. 若年性高血生の成績調查

1962年 / 第6号

7. 工場の災害と月経に就て

1963年 I 第 7 号

偶 感

牧竟吉

やがて一昔にも近くなるが，本誌の読者各位の御記憶 にはまだ新しからうと思う。

近畿の某絹糸工場が争議に入って，永い間ごたついた ときのことである。当時の新聞には,殆ど連日,その経過 が報道され，某紙は財界，産業界の名士談を連載した。

その中で，ある知名の土が次のような所懐を述べて居 たのである。 
「私は今度の事件を見て,今後の産業は,もはや営利一 辺倒では成り立たないと思った。これからは労㗢者のた めにも，ある程度は有利な労働条件を与克る必要がある う」という意見であった。

この話は一般の人達にとって，いがも目ざめた産業 人の述樯の上らと受けとれたか子知れないが, 私達の常 識からは到底肯定し難いものであった。勿論, 本誌の読 者各位もご同感のこと子思うが，本号が特別な機会であ ることに甘えて，当時私が云いたかったことを，ここに 述べさせていただきたいと思ら。

第一，今の世の中に「営利一边倒」でない中途半端な 産業でなけれ洋成りたたないといら考方方からして理解 住しむことである。私の上らな経済事情に弱い者です らも，まともな産業である限り，あくまでも営利一辺倒 であって汪しいと思って居るのだから，この話には当初 から驚かされてしまった。

その次に「今後は労働者のためにも，あるていど有利 な労働条件を与えなければならないであるら」とつぶく ところから推せば，いわゆる労働者にとって有利な条件 を与えることが，営利一辺倒では通れない，杂をもの 原因だという意味にとらざるを得ないのである。

更にこの記事を，読んで字の如くに受け取ってよけれ ば,この氏の考觉方では, 労働条件には, 経営に有利で 労働に不利なものと，労働に有利で経営に不利なるの が，はっきりと別々に，乙か子対立的に存在していて， 今までの営利一辺倒を目ざした産業では，はじめから労 働に不利な方ばかりが，計画的に採用されて居たことに なるのである。

そこに大争議が起り，少からず損害を蒙る事態を目前 にすると，今後は相当の覚悟を以て，労働者のたるにる 有利な学働条件を与える必要があううというところに想 到したものと思はれるのである。（労働条件には生活条 件も含まれる筈だから，この場合，学働と云拈らが労働 者と云物らが同じことである。）

いうまでもなく，吾々としては，労衝に不利な条件の もとでの仕事は能率も生産も低下するものと信じて居る のに，矢秃が経営にとって有利だと考党られて居り，又 その反対汇労働にとって有利な条件, 即ち能率も生産も 增進せざるを得ない労働条件のもとでは, 営利一边倒の 産業は成り立たないということになると, 最早, 吾々に は二の句がつげないのである。

それとしても，何故こつまで話が矛盾しなければなら ないか，を考えてみると、彼氏のいわゆる「労働者のため に有利な条件」といらのは，吾々が学えで来た「よき労
働条件」のことではなく「酷しい労苦を緩和する」とい う意味らしいことに気づくのである。しかしこの推察は 同時に彼氏等が「上き労働条件」なるものの本質を認識 しては居ないというところまで延長されるのであった。 その後要もなく、これが果して私の邪推でなかったこ とを思い知らされたのである。

これも某紙が特集した記事であった。ある会社が新採 用の社員を，ぞう受け入れるかといら話題の中で人事課 長なる人が「新社員諾君には出来るだけのことをしたい と思らがなにしろ会社は儲けなければならないので... ……いつる人事課は会社と社員との板ばさみになって若 労します」といら意味のことを述べていたのである。

要するに名士も課長も, 言葉こそ違克, 從業員に対し て，上き学働条件を以て遇すること入，会社が業績を進 めることつは，根本的に相反し，相容孔ないものだとい らことを，くれぐれも念を怙しているのである。

さて, ここでもら一度, 吾々の常識を復習してみる必 要があると思う。

いまさら乍ら,最もよい労働条件とは，肉体的であれ精 神的であれ，学㗢の本態である生理機能を発揮するに当 っての最も合理的で自然で無理のない方法の寄世集めと もいらべきものだから，エネルギー消費が最少となり， 従って疲労も軽く，労苦も最低となる一一の故にこそ 最大の効果をあげることができるのである。

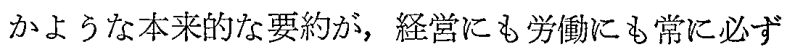
同時に，しかも同等に有利であることは正に当然の帰趨 でなけ机ばならない。

これ添どに「最も」づくめで一挙両得な事実を，何の 疑義むなげに頭から否定してか子る理由がどこにあるの だろらか。さすがに「だ゙伝統的の勘違い」とばかり即 断することはできなかったのである。

しかし産業経営には, 労働力の貢献に多くの期待をる つ必要のない場合がありらることも思い当るのである。

その一つは労働力が消耗品視されるときである。斬れ ば血の出る労㗢力を皿小鋪なみに考光ている経営者は, 最善の学㗢条件なぞついうものを要としていない，彼氏 等は機械技術の䓪進する現代には, 経験工や熟練者は無 用の長物之断定して憚らないのである。こんな職場の従 業員こそ不幸この上むないが，近来の上らな求人難に見 舞われると，中途半端な方針自体が一番先に行詰るので はなからうか。

又或は堅実という消極経営临籠って, 敢て能率增進を 企図しない代り，進歩的な学働条件を講ずる必要るない という大悟徹底家も実在して居るのである。 
更に，本来的の労㗢条件を側面から，亡ま亡゙わして居 ると思はれるものに，「産業福利」といら考え力がある。 いらまでもなく，事業主が労働者福祉のために行う事業 であるから恩恵が大きな背景をなして居ることに不思議 はないが，内容的には企業自体に対しても予期せず期待 もない利得をるたらさら゙るを得ない本質をもって居る。 畢竟, これはよさ労働条件」の一稜をなすものであるた め, いつしか両者が混同され，必然的に恩恵のベールが 「よき労働条件」をまで装㧍うに至ることは想見するに 難くないところである。

もう一つの問題は，動く人の生活条件に適正な基準が ないことだと思う。

他の労働条件については，既に多くの業種, それぞれ の作業に対して至適条件と恕限度とが定められ，又はそ の努力がなされつっあるから，これを目標にして生活条 汼の基準を求めることも不可能でなかららと思はれる。

但し，これに役立つ恕限度は，労基法の衛生規則が唱 っている働く者の保健限界などより遙かに高いものでな 㞦ばならないであらら。

一方，既に科学は，労動の基本である身心に亘る能力 の限界を窺和らとしているのだから, これに応乎して適 正な生活条件の探求がタイムリーな課題となることも遠 くないであるら。

乙かもそれは「健康で文化的な最低限度の国民生活」 対する具体的な標準であると同時に，無限の権利を保 留している最低限度以上の生活が，常に果して健康且文 化的でありらるや否やについての検討に資するところも 多大であろら。

要するに労働条件のららで，生活条件だけが，多々益 々辨ずという，観念的な現代では，会社と從業員との板 蚛さみになって吊し上げられるのは，敢て人事課長一人 虬は限らないのである。

蓋し，この難問解決の㷌蔥は，容易に想見しうる範囲 ではないが，例えば賏て天下の正論と自称された「金も ちは米を食え，びえ之人は麦を食え」の如き思想は，そ の緒にして既に抹殺されざるを得ないであろう。

（字句，原文のまま）

\section{あれから}

松下 正 信

あれから 5 年，昭和34年10月，日本産業衛生協会創立 30 周年記念视典に臨み, 我等協会結成以来の会員に対し
感謝状が授けられて以来，5年の歳月が流れた。

翌35年4月には，旧職の保健婦養成所長を退いたが， 産業衛生担当の非常勤講師として，保健婦養成事業には 依然，る程度の関係を保ってきた。

36年 4 月，岡山大学で開催の第34回総会席上, 名誉会 員に推菣され，鯉沼理事長から漞しくその証書を受讨た が，この際同氏から，交友40年に及ぶ前理事長南博士が 前立腺癌で順天堂病院入院中と知らされ，大いに驚き， 早速御見舞として吉備団子を贈ったが，䚻宅すると，令 夫人より，食欲不振の折柄ではすったが，久しぶりのこ ととて喜んで少々口にしたとの拓便りを受け，小ささか 愁眉を開いたのも束の間， 6 月，長逝の訃報に手にした 時は全く范然とした。南君は四高の 2 年先輩で，大正 9 年以来，公私共に親しくしていただいたので，悲痛の感 はをた格別だった。

38 年 4 月入学の, 福阔県立公圌衛生看護学校（旧名保 健婦養成所）第12回生に対する産業衛生の講義を最後と して，38年 9 月，在住 40 年以上に及んだ思い出の博多の 地を去り, 病妻学同伴して, 名古屋市外の息子夫妻の許 八転住した。

38年10月上京し，労研で三浦博士と対談をやったが， 同氏から，腪峻博士が近来，病状回復し，労研へも注と んど毎日顔を出されると聞いて大いに喜び，御宅へ電話 したが，伊豆地方へ旅行中とのことで，残念ながら馨䒨 （けいがい）に接し得なかった。越光て12月になってか ら，あまり元気を出し過ぎない上うにと忠告めいた便り をしたが，早速，命夫人代簐の返信が来て，同氏の近況 がわかり，安塔した。

39年 4 月，久留米市に批第37回総会に出唐して， 新進気鋭な学徒諸君の熱意ある報告を聴いて，少なから ず啓発され，また，3年振りで旧知諸君と閑談し得たこ 之は，深い喜びであった。わけても，名誉会員の近藤博 士が益々元気旺盛, 愈々健脚ぶりを発籍して, 学会終了 後，リュックサック携带で，対島へ渡航されると聞いて は，全く兜を脱いだ。その興味深い調查成績の発表が待 たれる。

本総会に出席して，またまた脳裡に浮んだことは，本 協会運営の将来ということであった。会場のロビーで， 東京医大の赤塚教授とも話しあったことだったが，一方 で，学会として産業医学界のイニシアチーブをとり，他 方では，協会として職場環境改善の推進役を努めること は，所謂二鬼を道うことともなり，その達成は必ずしも 安易ではあるまいと思われる。もとより本協会は単なる 研究一辺倒の衛生学会ではない。だが職場環境改善の推 